\title{
BARACK OBAMA, SYRIA, AND THE EXERTION OF AMERICAN MILITARY POWER
}

\author{
David Jervis \\ International Relations Department \\ Faculty of Political Science \\ UMCS
}

\begin{abstract}
This article reviews American policy toward Syria since the onset of its civil war there. It concentrates on debates and decisions about the use of American military power to influence events there.

Before 2014, President Barack Obama consistently refused to use military power and, while he did initiate military action against the Islamic State in the summer of 2014, many in and out of the administration thought he should do more. This article identifies reasons for Obama's hesitance and argues that some of his pre-2014 fears about using military power have been realized in later years.
\end{abstract}

Key words: Obama, Syria, Islamic State, military power

Hillary Clinton, former U.S. Secretary of State, once referred to the crisis in Syria as a 'wicked problem,' i.e., one involving 'particularly complex challenges that confound standard solutions and approaches. Wicked problems rarely have a right answer; in fact, part of what makes them wicked is that every option appears worse than the next.' ${ }^{\text {' }}$ A central question for the Obama administration over the course of the war has been whether the United States should employ the military option in Syria as a means to influence events there.

A way to consider American policy toward Syria after 2011 is to examine the different answers that have been given to that question. Policy can be divided into two periods: in the first, lasting from March 2011 until the summer of 2014, the U.S. sought the removal of the Bashar al-Assad government through diplomacy and sanctions. President Obama consistently resisted calls for using American military power to supplement or supplant those diplomatic efforts. Beginning in the summer of 2014, however, U.S. policy changed. It began to employ military

1 H. R. Clinton, Hard Choices (New York: Simon and Schuster, 2014), p. 389. 
force in the country and to implement some of the military actions that it had previously rejected. These policy changes were prompted by the emergence of the Islamic State in the summer of 2014 and Russia's military support for the Assad regime beginning in 2015. This article reviews American policy in the two periods, explains why policy changed, and argues that some of Obama's fears about the use of military power during the first period have come to fruition in the second.

\section{THE FIRST PERIOD: MARCH 2011-SUMMER OF 2014}

The United States and other Western democracies did not anticipate the Syrian crisis and were slow to respond to it. There were many reasons. When the challenge to the Assad regime first began in March 2011, the United States was dealing with a number of other complex foreign policy issues. In Iraq, it was deciding how many U.S. troops should remain after the scheduled December 2011 withdrawal of combat forces and then trying to persuade the Iraqis to agree to terms for their staying. In Afghanistan, that spring was devoted to deciding the size and pace of U.S. troop withdrawals. In Egypt, Hosni Mubarak, a longtime American friend, had been overthrown in February, while in March the United Nations Security Council passed a resolution that allowed the U.S. and its allies to undertake military action against Libya's Muammar Gaddafi.

Further adding to the belated recognition of the seriousness of the Syrian crisis was the widespread belief that Syria and Assad were different and would not be affected by the Arab Spring. Assad was somewhat popular in Syria, or at least not as reviled as Egypt's Mubarak had been. Moreover, the opposition to Assad was weak; his opponents were not unified and were often based outside the country, discrediting them in the eyes of many Syrians. Plus, Syrians needed only to look at their own history or across their borders to Lebanon and Iraq to see the impact of political instability on ethnically and religiously diverse societies. Assad, too, was thought to be different. A trained ophthalmologist who had had some schooling in London, he was thought to be something of a reformer. Leading American officials certainly thought so. John Kerry, then Chairman of the Senate Foreign Relations Committee and someone who had worked with Assad, argued soon after the anti-Assad protests began that the Syrian leader 'understands what is going on. [Syria] is a secular country. And I guarantee you, he's committed to trying to stay secular...., adding that, 'My judgment is that Syria will move, Syria change....' Similarly, Secretary of State Clinton asserted that many who had worked with Assad had concluded that '[Assad] is a reformer.'

2 D. Lesch, Syria: The Fall of the House of Assad (New Haven: Yale, 2013), pp. 11-18; Kerry and Clinton quoted in Emile Hokayem, Syria's Uprising and the Fracturing of the Levant (London: Routledge, 2013), p. 154. 
Western governments were hesitant to respond to the Syrian crisis because they had made an investment in diplomacy with Assad in the years prior to 2011 and did not want to sacrifice or abandon that effort. Obama had come to office committed to diplomacy with regional foes rather than pressuring them as the Bush administration had done. He adopted a softer tone and made an effort to deal diplomatically with Syria. Robert Ford was named ambassador, a position that had been vacant since 2005, and the U.S. began discussions with the Syrian regime on issues such as stability in Iraq, non-proliferation, and Syrian-Israeli peace. ${ }^{3}$

For all of these reasons, the American response to Syrian events was slow and, some would argue, unimaginative. As one former administration insider has argued, the U.S. response to Syria and other countries experiencing the Arab Spring was 'wholly reactive' and 'squandered precious opportunity to influence the course of events in the Middle East. ${ }^{4}$ The initial American policies sought to isolate the Assad regime and to pressure it to change its policies. To do so, the U.S. and the European Union imposed sanctions against certain individuals in the Syrian regime on April 29. These generally applied asset freezes and travel bans on Syrians directly involved in the violence as well as prohibitions on doing business with them. The U.S. also reversed an earlier decision to license the export of airplanes to the country. Continuing repression led to a new round of U.S. and EU sanctions in late May and the inclusion of Assad, himself, on the list. U.S. diplomats also expanded contacts with opposition figures throughout the summer of 2011. The most significant of these was the July 8 visit to Hama by U.S. ambassador Ford and French ambassador Eric Chevallier. Hama was a particularly important city for Syrian opposition forces, because Assad's father, Hafiz al-Assad, had launched a major attack there in 1982, killing as many as 10,000-20,000 people. During their July visit, the two ambassadors met opposition leaders and observed peaceful demonstrations. Ford also attended the funeral of a slain activist and was a vocal critic of the Syrian government. His activities angered pro-government supporters, and he was forced to leave the country in October 2011 after Syrian mobs attacked the U.S. embassy, his residence, and a convoy in which he was riding. ${ }^{5}$

Despite the growing violence in Syria over the summer of 2011, the United States had still not called for Assad's removal. That only happened on August 18, when Obama declared that 'for the sake of the Syrian people, the time has come for President Assad to step aside.' This announcement had been coordinated with $29-64$.

3 K. B. Kanat, A Tale of Four Augusts: Obama's Syria Policy (Ankara: SETA, 2015), pp.

4 V. Nasr, The Dangerous Price of Ignoring Syria in Nader Hashemi and Danny Postel, ed., "The Syrian Dilemma," (Cambridge, MA: MIT, 2013), pp. 213-14.

5 Kanat, op. cit., pp. 65-76; Anthony Shadid, U.S. Ambassador to Syria Leaves Damascus Amid Threats to Safety, "New York Times," (24 October 2011) available at www.nytimes. com/2011/10/25/world/middleeast/us-ambassador-to-syria-leaves-damascus-amid-threats-tosafety.html?_r=0 (accessed on 27 August 2016). 
the governments of Canada, Britain, France, Germany, and the UK to increase its effect. ${ }^{6}$ Obama's statement created a number of subsequent problems. It was in effect a statement without a strategy, because it assumed that Assad would leave power or be overthrown quickly--something predicted by intelligence agencies and as had happened with Egypt's Mubarak. The absolute demand also reduced American negotiating flexibility, because it did not allow for any sort of process to a transitional agreement that would allow Assad to remain in power, even if only briefly. The call for Assad's removal also reduced his desire to negotiate. Finally, Syria's opposition now believed that the U.S. was committed to acting to bring about Assad's removal, something it was not committed to do.

Assad's refusal to leave office and the continuing violence in Syria led to diplomatic efforts to resolve the crisis, first by the Arab League and then the United Nations. The U.S. strongly supported such efforts. The Arab League developed a peace plan that sought to promote dialogue between the regime and the opposition. Both sides agreed, although they may have done so reluctantly, but by early 2012 the Arab League mission had clearly failed.7 The United Nations then became more actively involved. A draft Security Council resolution calling for a ceasefire and a political transition was introduced in February 2012 but was vetoed by Russia and China. Soon after that failure, Kofi Annan, the joint envoy of the United Nations and the Arab League, drew up a plan to end the violence. This received insufficient support from the parties on the ground, and Annan resigned in disgust in August 2012, saying 'As an envoy, I can't want peace more than the protagonists, more than the Security Council or the international community, for that matter.' Annan's successor, Lakhdar Brahimi, resigned in May 2014 and expressed similar frustrations: 'I am ready to push the Sisyphean rock up the hill - but the problem is I can't even push the rock. It doesn't move."

It is not surprising that negotiations and the application of sanctions failed to remove the Assad regime. Assad is fighting for his survival and is unlikely to compromise, especially since he thinks he can win. ${ }^{9}$ His opponents remain divided

${ }^{6}$ Lesch, op. cit., pp. 150-161, Obama quoted at p. 160.

7 Lesch, op. cit., p. 157.

8 Annan quoted in Chris Doyle, Kofi Annan's resignation is no surprise, his Syria peace plan undermined, "Guardian," (2 August 2012) available at www.theguardian.com/commentisfree/2012/aug/02/kofi-annan-resignation-syria-peace-plan (accessed on 27 August 2016); Brahimi quoted in David Kenner and Colum Lynch, Syrian Peace Envoy Finally Admits Defeat, "Foreign Policy" (13 May 2014) available at http://thecable.foreignpolicy.com/posts/2014/05/13/syrian peace_envoy_finally_admits_defeat (accessed on 27 August 2016); see also, Magnus Lundgren, Mediation in Syria: Initiatives, Strategies, and Obstacles, 2011-2016, "Contemporary Security Policy" (2016) available at http://papers.ssrn.com/sol3/papers.cfm?abstract_id=2787157 (accessed on 23 August 2016).

9 For an example of Assad's thinking, see Syria's President Speaks: A Conversation with Bashar al-Assad, "Foreign Affairs" (March/April 2015) available at www.foreignaffairs.com/ interviews/2015-01-25/syrias-president-speaks (accessed on 23 August 2016) and Jonathon Tepperman, I Interviewed Bashar al-Assad About Syria's civil war. He's still too delusional to 
and have been unable to develop a consistent approach, must less the ability to implement it. Russia remains a strong supporter. Iran, too, supports Assad and would have a say in any cessation of the war, but Washington does not want it to participate in any international conference. Similarly, the American effort to employ sanctions to pressure the regime has not worked and is unlikely to work. Sanctions have a mixed record at best, are more likely to be successful over the longer term than the shorter term, and have much greater chance of success if implemented globally, conditions not present in the Syrian case. In addition, since the Assad government is fighting for its survival, it presumably is willing to tolerate sanctions.

In Syria, itself, the result of the Assad government's continuing repression and the failure of international efforts to remove him was the growth of a violent opposition, increasingly armed for foreign countries much as Assad was receiving support from Russia and Iran. The result of these actions was that by the late spring of 2012 a 'competitive proxy war,' had been created, i.e., one in which 'every escalation in favor of one side tends to trigger a response from the backers of the other. ${ }^{10}$ Over the next five years, the conflict became increasingly violent yet remained a stalemate that neither side could win and neither would contemplate the concessions to make peace. ${ }^{11}$

These events in Syria along with the failure of previous policy to remove Assad led to much discussion in the United States about the use of military power to achieve that goal or, minimally, to protect Syrian civilians from his attacks. The President had no interest in military action in this preliminary period: 'other than...diplomatic endeavors, U.S. foreign policy did not have a plan B to tackle the crisis and did not have any intention of becoming involved in the conflict with riskier options. ${ }^{12}$ The President told West Point graduates in May 2014, 'Since World War II, some of our most costly mistakes came not from our restraint, but from our willingness to rush into military adventures - without thinking through the consequences.' The President also doubted the utility of military force, telling the graduates that, 'As frustrating as it is, there are no easy answers, no military solution [in Syria] that can eliminate the terrible suffering anytime soon. ${ }^{13}$ Amer-

end it, "Washington Post" (30 January 2015) available at https://www.washingtonpost.com/ opinions/i-interviewed-bashar-al-assad-about-syrias-civil-war-hes-still-too-delusional-to-endit/2015/01/30/571671b4-a77f-11e4-a2b2-776095f393b2_story.html?utm_term=.106459069e33 (accessed on 23 August 2016).

${ }^{10}$ M. Lynch, The New Arab Wars: Uprisings and Anarchy in the Middle East (New York: Public Affairs, 2016), pp. 105-139; quoted at p. 130.

${ }^{11}$ M. Fisher, Syria's Paradox: Why the War Only Ever Seems to Get Worse, "New York Times" (26 August 2016) available at www.nytimes.com/2016/08/27/world/middleeast/syria-civil-war-why-get-worse.html (accessed on 26 August 2016); Lynch, The New Arab Wars, op cit., pp. 189-224.

${ }^{12}$ Kanat, op. cit., p. 106.

${ }^{13}$ White House, Office of the Press Secretary, Remarks by the President at the United States Military Academy Commencement Ceremony (28 May 2014) available at www.whitehouse. 
ica's experiences in Iraq and Libya were also relevant: Obama found it 'very difficult to imagine a scenario by which our involvement in Syria would have led to a better outcome, short of us being willing to undertake an effort in size and scope similar to what we did in Iraq. ${ }^{14}$

Obama's reluctance to use military power can be illustrated by his rejection of a number of proposals for military action in these years. The most obvious proposal at the outset of the Syrian crisis was to repeat in Syria what U.S. and NATO forces had done in Libya in 2011. There, NATO forces acting with the support of the Arab League and with a United Nations mandate, had employed a bombing campaign nominally to protect Libyan civilians from the government of Muammar Qaddafi but with the ultimate purpose of removing the Libyan dictator from office. ${ }^{15}$ However, the Syrian case was very different politically and militarily. Secretary of State Clinton had ruled out this option almost from the start, declaring as early as March 27, 2011 that the U.S. would not get involved in Syria as it had in Libya. Why? Because in Libya there had been an international consensus for action, a call for action from the Arab League, and a UN Security Council resolution, things that were 'not going to happen' in the Syrian case. The military also had objections: Syria had a large and competent military force and a sophisticated air defense system. Moreover, as time went on, the Libyan intervention appeared less and less successful. ${ }^{16}$

A second proposal for military action was to create safe havens to protect civilians. ${ }^{17}$ While the humanitarian rationale for safe havens is clear, the military identified a number of problems with implementing them. The Bosnian case demonstrated that the mere establishment of safe havens does not protect those within them, so ways would have to be devised to physically protect the territories. This would probably require the creation of a no-fly zone to keep Syrian army planes away from the region, but doing so would be far more difficult than was the

gov/the-press-office/2014/05/28/remarks-president-united-states-military-academy-commencement-ceremony (accessed on 8 September 2016).

${ }^{14}$ Obama quoted in Kanat, op. cit., p. 135.

${ }^{15}$ J. Becker and S. Shane, Hillary Clinton, 'Smart Power' and a Dictator's Fall, ' 'New York Times" (27 February 2016) available at www.nytimes.com/2016/02/28/us/politics/hillary-clinton-libya.html?_r=0 (accessed on 29 March 2016; Ivo H. Daalder and James G. Stavridis, NATO's Victory in Libya: The Right Way to Run an Intervention, "Foreign Affairs" (March/April 2012) available at www.foreignaffairs.com/articles/libya/2012-02-02/natos-victory-libya (accessed on 17 April 2016).

${ }^{16}$ Clinton quoted in Lesch, op. cit., p. 151; David Fitzgerald and David Ryan, Obama, US Foreign Policy and the Dilemmas of Intervention (New York: St. Martin's, 2014), pp. 116-117; Obama quoted in Thomas L. Friedman, Obama on the World, "New York Times" (8 August 2014) available at www.nytimes.com/2014/08/09/opinion/president-obama-thomas-1-friedman-iraq-and-world-affairs.html (accessed on 2 April 2016).

${ }^{17}$ A.-M. Slaughter, Syria is Not the Problem from Hell - But If We Don't Act Quickly, It Will $B e$, in Hashemi and Postel, ed., op. cit., pp. 93-99; Mary Kaldor, A Humanitarian Strategy Focused on Syrian Civilians, in Ibid., pp. 147-159. 
creation of no-fly zones over Libya had been. The Chairman of the Joint Chiefs of Staff, Martin Dempsey, argued in July 2013 that establishing a no-fly zone would require the deployment of 'thousands' of American forces, create risks such as 'the loss of U.S. aircraft, which would require us to insert personnel recovery forces.' Another set of concerns related to the Syrian government's response. Suppose it challenged planes enforcing the no-fly zone? Suppose its military entered the area on the ground and not through the air, as Saddam Hussein had done in 1996 against Kurdish safe havens in Iraq? Given these uncertainties, while the Pentagon was tasked to develop contingency plans for no-fly zones, Obama remained unwilling to authorize them. ${ }^{18}$

The President's aversion to aversion to the use of military force can be best illustrated, however, by examining the occasion when he came closest to authorizing it, i.e., in response to the Syrian government's use of chemical weapons in August 2013. Following reports in the summer of 2012 that chemical weapons were being moved out of storage and mixed, perhaps in preparation for use, the administration considered and then rejected a number of pre-emptive military actions. The Pentagon doubted that air strikes would be effective and that 75,000 troops would be needed to find and secure the chemical weapons stockpiles, while senior foreign policy advisors worried about the legal implications of acting without the UN's approval. ${ }^{19}$ Consequently, the focus shifted to deterring Syria from the actual use of the weapons it had. Obama issued a warning to the government via Russia and Iran, its most important allies. He also issued an off-the-cuff public warning on August 20, 2012: 'We have been very clear to the Assad regime...that a red line for us is we start seeing a whole bunch of chemical weapons moving around or being utilized. ${ }^{20}$ While Obama did not explicitly threaten military action, the 'red line' phrase suggested a commitment to do so, but there was no follow-up planning for military action in response to a future

${ }^{18}$ Dempsey quoted in Gordon Lubold, Breaking: Every Military Option in Syria Sucks, www.foreignpolicy.com (23 July 2013) available at www.foreignpolicy.com/articles/2013/07/22/ breaking_every_military_option_in_syria_sucks_dempsey_intervention_billion_dollars_a_ month (accessed on 26 August 2016); Mark Landler and Thom Shanker, Pentagon Lays Out Options for U.S. Military Effort in Syria, "New York Times," (22 July 2013) available www.nytimes. com/2013/07/23/world/middleeast/pentagon-outlining-options-to-congress-suggests-syria-campaign-would-be-costly.html?pagewanted=all (accessed on 27 August 2016)

${ }^{19}$ Landler and Shanker, Pentagon Lays Out Options for U.S. Military Effort in Syria, op. cit.; Leon Panetta, Worthy Fights: A Memoir of Leadership in War and Peace (New York: Penguin, 2014) p. 448.

${ }^{20}$ Obama quoted in Glenn Kessler, The Fact Checker: President Obama and the "red line" on Syria's chemical weapons, "Washington Post" (6 September 2013) available at www.washingtonpost.com/blogs/fact-checker/wp/2013/09/06/president-obama-and-the-red-line-on-syrias-chemical-weapons/ (accessed on 14 October 2014; Peter Baker, et al, Off-the-Cuff Obama Line Put U.S. in Bind on Syria, "New York Times" (4 May 2013) available at www.nytimes. com/2013/05/05/world/middleeast/obamas-vow-on-chemical-weapons-puts-him-in-tough-spot. html?pagewanted=all (accessed on 15 October 2014). 
use of chemical weapons. While the statement was intended to deter the Syrian government, it did not do so as there were reports throughout 2013 of continuing chemical weapons use. A major attack that could clearly be attributed to the Syrian government occurred in August 2013. Obama then made a more explicit threat, saying the U.S. would respond with 'military action against Syrian regime targets.' Now there appeared to be even more justification for military action. Not only had the Syrian government committed a crime against humanity, but Obama's prior statements imposed what many considered to be an obligation to act. Secretary of State Kerry, who had succeeded Clinton in early 2013, argued for military action, because doing so 'is directly related to our credibility and whether countries still believe the United States when it says something,' while Vice President Joe Biden argued that 'big nations don't bluff.' Preparations were made to launch missile attacks from ships stationed in the Mediterranean Sea on Syrian weapons delivery systems, command and control systems and intelligence bases to prevent future chemical attacks. ${ }^{21}$

However, Obama soon began to have second thoughts, saying he would act only if the Congress approved, something that he had never done previously and something that was unlikely to happen. The President later expressed the reasons for his changed thinking: very important was 'our assessment that while we could inflict some damage on Assad, we could not, through a missile strike, eliminate the chemical weapons themselves,' with the resulting 'prospect of Assad having survived the strike and claiming he had successfully defied the United States, that the United States had acted unlawfully in the absence of a UN mandate, and that would have potentially strengthened his hand rather than weakened it.' He also rejected the argument about American credibility: 'dropping bombs on someone to prove that you're willing to drop bombs on someone is just about the worst reason to use force. ${ }^{22}$

Whatever the wisdom of that position, the U.S. had created a dilemma for itself, having first threatened military action and then refusing to do so. Fortunately, a diplomatic solution appeared: asked if there was anything the Syrian leader could do to prevent military action, Kerry responded by saying, 'Sure, he could turn over every bit of his chemical weapons to the international community in the next week,' although he added that 'he isn't about to do it...' It is not clear if this was a casual remark, a reflection of conversations Kerry had been having with allies, or a serious diplomatic offer, but Russia quickly acted on it, persuading the Syrian leader to adopt the Chemical Weapons Convention and to develop a plan to destroy all the country's chemical weapons. This seems to have worked, because by September 2015 the Syrian government had destroyed $98.8 \%$ of its most

${ }^{21}$ Kerry and Biden quoted in Goldberg, The Obama Doctrine, op. cit.; Kanat, A Tale of Four Augusts, op. cit., p. 123.

${ }^{22}$ Obama quoted in Goldberg, The Obama Doctrine, op. cit. 
destructive chemical weapons, although there are continuing reports of chemical weapons use by the government and the opposition. ${ }^{23}$

This episode clearly demonstrated that Obama would not authorize the use of American military power in Syria, even in the face of blatant Syrian disregard for American threats and despite the advice of many of his foreign policy and military advisers. Would he contemplate the indirect use of American military resources? For example, would he authorize the provision of American military aid to moderate Syrian armed opposition forces? This idea had wide appeal: CIA Director David Petraeus proposed a plan in early 2012 that gained the support of Secretary of State Clinton, Secretary of Defense Leon Panetta, and Dempsey of the Joint Chiefs of Staff. For these and other supporters, arming the opposition would equalize an unfair fight and give the United States greater influence among Syria's fractured military opposition, while not doing so would reduce the influence of groups promoting a secular post-Assad future. Yet Obama saw many problems with the proposal. He later described as a 'fantasy' the 'idea that we could provide some light arms or even more sophisticated arms to what was essentially an opposition made up of former doctors, farmers, pharmacists and so forth.' Historical evidence, too, argued against this option: Obama asked the CIA to identify cases where the provision of arms to insurgent groups was successful, and in Obama's words, 'they couldn't come up with much.' The Syrian case would be an exceptionally difficult one: because there are so many different opposition groups one must wonder how the U.S. would be able to provide military aid to 'its' preferred forces yet prevent the arms from falling into the wrong hands. Even if the United States provided arms to the opposition, it would be unlikely to provide enough to make a dramatic difference in the course of the fighting, so the hope was that the assistance would help strengthen the opposition to the point where a stalemate was reached and negotiations follow. Yet does the provision of arms facilitate a diplomatic solution; might doing so just as easily encourage the opposition to fight on and not negotiate? Finally, what would happen if, after the provision of arms, the fortunes of the recipients eroded? By that point, the U.S. would have become more committed to it and might be faced with the question of whether to increase its role still further. ${ }^{24}$

${ }^{23}$ Kerry quoted in Clinton, Hard Choices, op. cit., p. 396; Christopher M. Blanchard, Carla E. Humud, and Mary Beth D. Nikitin, Armed Conflict in Syria: Overview and U.S. Response, "Congressional Research Service" (9 October 2015) available at www.fas.org/sgp/crs/mideast/ RL33487.pdf (accessed on 25 August 2016).

${ }^{24}$ Obama quoted in Michael D. Shear and Julie Hirshfeld Davis, While Offering Support, Obama Warns That U.S. Will Not be 'Iraqi Air Force', "New York Times" (8 August 2014) available at www.nytimes.com/2014/08/09/world/middleeast/while-offering-support-obama-warnsthat-us-wont-be-iraqi-air-force.html (accessed on 25 August 2016); Dexter Filkins, The Thin Red Line: Inside the White House Debate Over Syria, "The New Yorker," (13 May 2013) available at www.newyorker.com/magazine/2013/05/13/the-thin-red-line-2 (accessed on 27 August 2016); Marc Lynch, Shopping Option C for Syria: Against Arming the Rebels in Hashemi and Postel, ed., op. cit., pp. 184-188; Obama comment on CIA study in quoted in Mark Mazzetti, CIA Study 
Gradually, however, by early2013 Obama was persuaded to endorse the idea in limited form. By that time, the position of the moderate opposition had worsened, while that of opposition groups linked with al-Qaeda had improved, as had that of Assad. In light of those factors, in April Obama authorized a program in which small groups of Syrian opposition forces would be trained and armed in Jordan and then return to Syria to train still more fighters. The program was to be managed by the CIA rather than the Defense Department to reduce publicity and to avoid legal complications of authorizing the overthrow of a foreign government. ${ }^{25}$ It was not clear what the purpose of the funds was. At least a dozen rationales were articulated in the first twelve days after the decision was announced, including strengthening the opposition on the ground, strengthening moderate elements within the opposition, promoting a political solution, and preventing the disintegration of the country. This led one observer to argue that 'Never in the history of third-party interventions in civil wars has so much been asked of so little. ${ }^{26}$ Nonetheless, the program continued and in the spring of 2014, the U.S. had quietly begun to provide more military aid to selected Syrian rebel groups, providing anti-tank missiles and contemplating the provision of missiles capable of shooting down government airplanes and helicopters. ${ }^{27}$

\section{THE SECOND PERIOD: SUMMER OF 2014-PRESENT}

If U.S. Syria policy before the summer of 2014 could be characterized as a 'minimalist' one that relied on political rather than military means, policy after the summer of 2014 was more assertive and largely military. ${ }^{28}$ The primary reason for the dramatically changed approach was the emergence of the Islamic State

of Covert Aid Fueled Skepticism About Helping Syrian Rebels, "New York Times" (14 October 2014) available at www.nytimes.com/2014/10/15/us/politics/cia-study-says-arming-rebels-seldom-works.html (accessed on 8 September 2016).

${ }^{25}$ M. Mazzetti, R. F. Worth, and Michael R. Gordon, Obama's Uncertain Path Amid Syria Bloodshed, "New York Times" (22 October 2013 available at www.nytimes.com/2013/10/23/world/ middleeast/obamas-uncertain-path-amid-syria-bloodshed.html (accessed on 27 August 2016).

${ }^{26}$ M. Zenko, Obama's "Alice in Wonderland" Strategy in Syria, "Foreign Policy" (25 June 2013) available at http://foreignpolicy.com/2013/06/25/obamas-alice-in-wonderland-syria-strategy/ (accessed on 27 August 2016).

${ }^{27}$ Remarks by the President at the United States Military Academy Commencement Ceremony (28 May 2014) available at < http://www.whitehouse.gov/the-press-office/2014/05/28/remarks-president-united-states-military-academy-commencement-ceremony (accessed on 26 August 2016); Catherine A. Traywick, Syrian Opposition Needs Weapons, Not Fighters, "Foreign Policy" (7 May 2014) available at $<$ http://blog.foreignpolicy.com/posts/2014/05/07/syrian_opposition_needs_weapons_not_fighters (accessed on 26 August 2016).

${ }_{28}$ J. Diehl, Obama's Minimalist Middle East Muddle, "Washington Post"(15 May 2016) available at www.washingtonpost.com/opinions/obamas-minimalist-mideast-muddle/2016/05/15/ 4f8e5a8e-1861-11e6-924d-838753295f9a_story.html?utm_term=.c99e6dladbda (accessed on 29 August 2016). 
(also referred to as ISIS, IS, ISIL, and Daesh), described by the Congressional Reference Service as a 'transnational Sunni Islamist insurgent and terrorist group that controls large areas of Iraq and Syria, has affiliates in several other countries, has attracted a network of global supporters, and disrupts international security with its campaigns of violence and terrorism.' The group formed soon after the American invasion of Iraq, calling itself al-Qaeda in Iraq. Its extreme violence led some Iraqis to side with American forces during the surge of 2006-2007, resulting in a significant reduction in ISIS's influence. The group then retreated to Syria, regrouped with the onset of the civil war there, and then increased its influence among Iraqi Sunnis largely due to the sectarian rule of Iraq's Shia prime minister, Nouri al-Maliki. The group changed its name in this period, becoming the Islamic State in Iraq and Syria, an indication of both its territorial ambitions and its growing involvement in the Syria civil war, where it fought against both the Assad government and its more moderate opponents. By 2013, it controlled much of northeastern Syria. From that base, it launched attacks into Iraq in early 2014 and made major gains, capturing Fallujah and Ramadi in January and Mosul in June. ${ }^{29}$

The United States was slow to react to these events. There was a failure to perceive the seriousness of the ISIS threat and to the possibility that it might seek to acquire territory. After its advances in early 2014, Obama described the group as follows: 'The analogy we use around here sometimes, and I think is accurate, is if a J.V. team puts on Lakers uniforms, that doesn't make them Kobe Bryant.' Intelligence professional took the threat more seriously but concentrated more on the threat of the foreigners fighting for ISIS and the danger that they would commit terrorist acts upon returning home rather than the possibility that it would seek to control territory. As one senior Army general remarked, 'We were surprised by their regional ambitions, the speed of their advance into Mosul and the collapse of the Iraqi security forces. ${ }^{30}$

At first, the U.S. responded to ISIS in an ad hoc and reactive way. In July, US Special Forces entered Syria in an unsuccessful effort to rescue hostages held by ISIS. In August, air surveillance of ISIS sites was begun and the U.S. conducted airstrikes in Iraq both to protect the city of Erbil and ease the threat to

${ }^{29}$ C. R. Blanchard and Karla Humud, The Islamic State and U.S. Policy, "Congressional Research Service" (27 June 2016) available at https://fas.org/sgp/crs/mideast/R43612.pdf (accessed on 28 August 2016). Zachary Laub and Jonathon Masters, Backgrounder: Islamic State in Iraq and Syria, "Council on Foreign Relations" (10 August 2016) available at www.cfr.org/iraq/islamic-state/p14811 (accessed on 27 August 2016).

${ }^{30}$ Obama quoted in Shreeya Sinha, Obama's Evolution on ISIS, "New York Times" (9 June 2015) available at www.nytimes.com/interactive/2015/06/09/world/middleeast/obama-isis-strategy.html (accessed on 25 August 2016); ISIS Baffling U.S. Intelligence Agencies, "The Daily Beast" (15 August 2014) available at www.thedailybeast.com/articles/2014/08/14/isis-still-baffles-us-intelligence-agencies.html (accessed on 27 August 2016); general quoted in Peter Baker and Eric Schmitt, Many Missteps in Assessment of ISIS Threat ${ }_{2}$ "New York Times" (29 September 2014) available at www.nytimes.com/2014/09/30/world/middleeast/obama-fault-is-shared-in-misjudging-of-isis-threat.html?_r=0 (accessed on 29 August 2014). 
the Christian Yazidi community that ISIS had threatened to wipe out. ${ }^{31}$ A more formal and detailed policy was announced in September. It relied largely on military and intelligence capabilities to 'destroy ISIL through a comprehensive and sustained counterterrorism strategy.' This strategy included a number of military activities--use of airstrikes against ISIS targets and increased assistance to those fighting ISIS on the ground - that Obama had not used previously. While the President concentrated on Iraq in his speech, those policies would also be used in Syria, although to a lesser extent. ${ }^{32}$

Although the elements of U.S. policy were similar in Iraq and Syria, much more attention was given to Iraq. The de-emphasis on Syria was a consequence of two elements of the new strategy. First, the U.S. had turned its attention from Assad to a new enemy and one that was active in Iraq as well as Syria. Moreover, the geographical emphasis in the fight against ISIS was Iraq, not Syria. According to Dempsey, Chairman of the Joint Chiefs of Staff, the ISIS threat 'will have to be addressed on both sides of what is essentially at this point a nonexistent border,' but this is an 'Iraq-first strategy.' The U.S. has different goals in the two countries, according to Dempsey: 'We can destroy ISIL in Iraq,' and 'disrupt ISIL in Syria.' ${ }^{33}$ This emphasis can be demonstrated by the number and location of American airstrikes, the central element of its military activities, since 2014. As of September 13, 2016, the U.S. had conducted a total of 11,558 air strikes, $6,657(57 \%)$ in Iraq and 4,901 (42\%) in Syria..$^{34}$

Another aspect of the new policy was a reinvigorated effort to train and equip the Syrian opposition. Up to $\$ 500$ million was authorized in September 2014 to recruit anti-ISIS fighters, provide tactical and strategic training for approximately eight weeks and then send them to Syria to fight ISIS. In addition to training, the groups would receive small arms, vehicles and communications equipment. The newly-trained force would concentrate on fighting ISIS in Syria, not Assad. As General John Allen, coordinator of the coalition against ISIS, argued, while there 'could be elements [of the newly-created force] ...that clash with the regime.... the intent is not to create a field force to liberate Damascus.' The plan was modified in October 2015 to concentrate on equipping vetted fighters within Syria rather

${ }^{31}$ M.Landler and Helene Cooper, Obama Authorizes Air Surveillance of ISIS in Syria, "New York Times" (26 August 2014) available at www.nytimes.com/2014/08/26/world/middleeast/ obama-syria-ISIS.html (accessed on 25 August 2016); Sinha, Obama's Evolution on ISIS, op. cit.

${ }^{32}$ Transcript of Obama's Remarks on the Fight Against ISIS, "New York Times" (10 September 2014) available at www.nytimes.com/2014/09/11/world/middleeast/obamas-remarks-on-thefight-against-isis.html (accessed on 25 August 2016).

${ }^{33}$ Dempsey quoted in Gayle Tzemach Lemmon, Fight the Islamic State in Iraq? Sure. In Syria? Not So Much., "Defense One" (16 September 2014) available at http://www.defenseone.com/ ideas/2014/09/fight-islamic-state-iraq-sure-syria-not-so-much/94283/?oref=defenseone_today_nl (accessed on 27 August 2016), emphasis in original.

${ }^{34}$ Operation Inherent Resolve: Targeted Operations Against ISIL Terrorists, "Department of Defense" available at www.defense.gov/News/Special-Reports/0814_Inherent-Resolve (accessed on 16 September 2016). 
than training new ones outside the country. By the Spring of 2016, the President was contemplating providing more sophisticated weapons to opposition forces, developing a proposal in April to give them weapons that would allow for attacks on regime aircraft and artillery. ${ }^{35}$

Despite increased aid to Syria's armed opposition, America remained committed to a political solution to end Syria's civil war. As Secretary of State Kerry argued soon after Obama's speech, the 'truth is there never has been a military solution to Syria's civil war. The only way forward is and always has been and remains today a negotiated political solution ultimately. ${ }^{36}$ However, with the focus now on ISIS, the United States gradually began to alter both its goals for any negotiated settlement and its preferred negotiating process. While the U.S. had long insisted that Assad must leave office, it came to abandon that goal, if only implicitly. Compare Kerry's statement in October 2014 that there will be no peace in Syria 'as long as Assad remains the focus of power there,' with his January 2015 statement that merely called for the Syrian president to change his policies: 'It is time for President Assad, the Assad regime, to put their people first and to think about the consequences of their actions, which are attracting more and more terrorists to Syria, basically because of their efforts to remove Assad. ${ }^{37}$ Obama conveyed a similar message; asked at a November 2014 news conference whether the US was actively discussing ways to remove Assad as part of any political transition, he answered 'no.' By March 2015, Kerry indicated that the U.S. would even be willing to negotiate with Assad 'if he's ready to have a serious negotiation about the implementation of Geneva I,' i.e., the UN-supported transi-

${ }^{35}$ R. Chandrasekaran, Syrians to be trained to defend territory, not take ground from jihadists, officials say, "Washington Post" (22 October 2014) available at www.washingtonpost. $\mathrm{com} /$ world/national-security/syrians-to-be-trained-to-defend-territory-not-take-ground-from-jihadists-officials-say/2014/10/22/8ca13cf2-5a17-11e4-bd61-346aee66ba29_story.html (accessed on 27 August 2014); Allen quoted in Karen De Young, U.S. officials consider striking another militant group in Syria, Jahbat al-Nusra, "Washington Post" (3 November 2014) available at www.washingtonpost.com/world/national-security/us-officials-consider-striking-another-militant-group-in-syria-jabhat-al-nusra/2014/11/03/86a19bac-6382-11e4-9fdc-d43b053ecb4d_story. $\mathrm{html}$ ?utm_source=Sailthru\&utm_medium $=$ email\&utm_term $=*$ Morning\%20Brief\&utm_campaign $=2014$ _MorningBrief\%2011\%2004\%2014 (accessed on August 27, 2016); Blanchard and Humud, The Islamic State and U.S. Policy, op. cit.; Adam Entous, U.S. Readies "Plan B" to Arm Syria Rebels, "Wall Street Journal" (12 April 2016) available at http://www.wsj.com/articles/u-sreadies-plan-b-to-arm-syria-rebels-1460509400 (accessed on August 28, 2016).

${ }^{36}$ Kerry quoted in Department of State, Remarks at Syria Ministerial (24 September 2014) available at http://www.state.gov/secretary/remarks/2014/09/232086.htm (accessed on 8 September 2016).

${ }^{37}$ Shifting Realities in Syria, "New York Times," (24 January 2015) available at www.nytimes.com/2015/01/25/opinion/sunday/shifting-realities-in-syria.html (accessed on 21 August 2016); Anne Barnard and Somini Sengupta, U.S. Signals Shift on How to End Syrian War, "New York Times" (19 January 2015) available at www.nytimes.com/2015/01/20/world/middleeast/ussupport-for-syria-peace-plans-demonstrates-shift-in-priorities.html (accessed on 21 August 2016). 
tion plan..$^{38}$ One reason the U.S. had modified its position on Assad was fear that his immediate removal would create a political vacuum that could be exploited by radical groups, as had happened after the removal of Saddam Hussein and Muammar Qaddafi. As a Rand Corporation study on possible alternative futures in Syria had concluded, while the collapse of the regime was not likely, it would be "the worst possible outcome for U.S. strategic interests. ${ }^{39}$

The framework proposed for negotiations also changed. While the U.S. had long supported UN-organized talks seeking to find a comprehensive solution to the Syrian crisis, i.e., a top-down approach, it now began to focus on a bottom-up approach, i.e., establishment of local cease-fires as a means of stopping the fighting in certain areas. There was also a greater willingness to work with Russia, an active supporter of Assad's government, to reach those cease-fires. For example, the U.S. and Russia reached a 'cessation of hostilities' agreement in February 2016 that called on all parties to the Syrian conflict to stop fighting and to allow the flow of humanitarian aid. Another effort was made in July, after repeated violations of the cessation of hostilities agreement, when Kerry and Sergei Lavrov, his Russian counterpart, reached a tentative agreement that, in Kerry's words, would 'help restore the cessation of hostilities, significantly reduce violence and help create the space for a genuine political transition.' The specifics of that agreement were only finalized in September 2016. ${ }^{40}$

It is inevitable that there will be critics any time the U.S. uses its military power. What is unusual in this case is that present and former members of the administration have been publicly critical. Obama, himself, wondered about the utility of this approach in Syria: 'We've got a campaign plan that has a strong chance for success in Iraq,' but 'I think Syria is a more challenging situation. ${ }^{41}$

${ }^{38}$ Obama quoted in David Kenner, Rewriting Syria's War, "Foreign Policy" (18 December 2014) available at http://foreignpolicy.com/2014/12/18/syria-assad-ceasefires-surrender-nir-rosen-hd-centre-report/ (accessed on 24 August 2016); Kerry quoted in Jeremy Diamond, John Kerry: U.S. Must Eventually Negotiate with Assad, "CNN" (16 March 2015) available at http://edition. cnn.com/2015/03/15/politics/john-kerry-negotiate-assad-syria/ (accessed on 21 August 2016).

${ }^{39}$ Andrew M. Liepman, Brian Nichiporuk, and Jason Killmeyer, Alternative Futures for Syria: Regional Implications and Challenges for the United States (Santa Monica, CA.: Rand Corporation, 2014) available at www.rand.org/pubs/perspectives/PE129.html (accessed on 21 August 2016).

${ }^{40}$ A putative agreement between Russia and America offers little hope, "Economist" (6 August 2016) available at www.economist.com/news/middle-east-and-africa/21703406-putativeagreement-between-america-and-russia-offers-little-hope-kerry-talks (accessed on 27 August 2016); Gardiner Harris, U.S. and Russia Agree on Steps to Combat ISIS in Syria, "New York Times" (15 July 2016) available at www.nytimes.com/2016/07/16/world/middleeast/us-and-russia-agree-on-steps-to-combat-isis-in-syria.html (accessed on 27 August 2016); David E. Sanger and Anne Barnard, Russia and the United States Reach New Agreement on Syria Conflict, "New York Times" (9 September 2016) available at www.nytimes.com/2016/09/10/world/middleeast/ syria-john-kerry-ceasefire-deal-russia.html (accessed on 13 September 2016)..

${ }^{41}$ Obama quoted in Peter Baker and Brian Knowlton, Obama Acknowledges U.S. Erred in Assessing ISIS, "New York Times" (28 September 2014) available at www.nytimes.com/2014/09/29/ world/middleeast/president-obama.html (accessed on 25 August 2016). 
Some within the administration question the priority given to Iraq. One former official identifies the conflicting emphases and tactics: 'I feel like half the administration is saying, "Put us in the game and let us do this right," and the other half is saying "No, we are going to gingerly handle Syria with kid gloves and focus on yielding real results in Iraq. ${ }^{42}$ Those who call for more attention to Syria argue that the Syrian and anti-ISIS wars are linked, because the repression of the Assad government was an important reason why disenchanted Sunnis joined ISIS and that it will continue to have their support as long as Assad is in power. ${ }^{43}$

Those with professional responsibility for and experience in Syria were among the most critical of the new policy. Robert Ford, the former ambassador to the country, has argued that the 'current U.S. strategy in Syria isn't working.' Despite bombing and support for Syrian opposition forces, 'Merely continuing to inject small amounts of aid and men in the fight won't sustainably contain the jihadis or be sufficient to reach the political negotiation the administration keeps hoping for.' Instead, Ford proposes working to unify the Syrian opposition and their foreign backers on a plan to fight ISIS and work for a negotiated settlement to the Syrian war and then to providing material assistance only through that unified structure. ${ }^{44}$

More recently, in June 2016, more than fifty mid-level Foreign Service officers filed a 'dissent channel' memo to express their disapproval with U.S. policy. They argued that 'achieving our objectives will continue to elude us if we do not include the use of military force as an option to enforce the Cessation of Hostilities and compel the Syrian regime to abide by its terms as well as negotiate a political solution in good faith.' Specifically, the memo called for a 'more militarily assertive U.S. role in Syria, based on the judicious use of stand-off and air weapons, which would undergird and drive a more focused and hardnosed U.S.-led diplomatic process.' The authors recognized the risks of their proposals: 'We recognize that military action is not a panacea, and that the Asad regime might prove more resilient even in the face of U.S. strikes. We further recognize that the risk of further deterioration in U.S.-Russian relations is significant and that military efforts to stop the Asad regime's relentless bombardment of the Syrian people may yield a number of second-order effects.' However, perpetuation of the status quo 'will continue to present increasingly dire, if not disastrous, humanitarian, diplomatic, and terrorism-related challenges.' Secretary of Kerry, who was thought to be in

${ }^{42}$ Quoted in Gayle Tzemach Lemmon, Obama Insiders Divided About Shifting the Fight From Assad to ISIS, "Defense One" (3 February 2015) available at www.defenseone.com/threats/2015/02/ obama-insiders-fume-white-house-strategy-fight-isis/104481/ (accessed om 24 August 2016).

${ }^{43}$ N. Bonsey, What Obama Doesn't Understand About Syria, "Foreign Policy" (26 November 2014) available at http://foreignpolicy.com/2014/11/26/what-obama-doesnt-understand-aboutsyria/ (accessed on 24 August 2016).

${ }^{44}$ R. S. Ford, America is Losing the War in Syria, "Foreign Policy (9 March 2015) available at http://foreignpolicy.com/2015/03/09/america-is-losing-in-the-war-against-the-islamic-stateand-assad-heres-a-grand-plan/ (accessed on 28 August 2016). 
agreement with the memo and of even stronger military measures, had made similar arguments in decision-making councils, but he could not publicly endorse the memo as that would entail a break with the president. ${ }^{45}$

James Jeffrey, a former ambassador to Iraq, also advocates a more sustained military effort, including sending combat troops. He has made a proposal to deploy several brigades of approximately five thousand troops each to the region to provide a reserve to support local forces: their role 'would not be to take over from local and regional forces, but rather to augment them.' Doing so would demonstrate America's commitment and end the 'logical absurdity' that, while it 'asserts that the counter-ISIS fight is its own war...it demands that other, far less capable forces suffer heavy casualties... while it risks not a single soldier beyond a few special forces. ${ }^{46}$

\section{WILL OBAMA’S FEARS ABOUT MILITARY POWER BE REALIZED?}

Two years have passed since Obama announced his new approach to Syria and Iraq. While it is too early to evaluate the success of the policy, enough time has passed to demonstrate that some for the President's fears about using military power have appeared. Three will be identified here: the slippery slope toward greater involvement, risks of relying on local irregular military forces, and the danger of weapons falling into the wrong hands.

\section{SLIPPERY SLOPE}

A perennial American fear is that the initial exertion of military force will be followed by others and eventually large numbers of combat troops will be sent, as happened in Vietnam. Obama had often cited his concern about 'mission creep' or of a 'slippery slope' as a reason to avoid the use of American force. Those concerns were obviously overcome with the September 2014 decision to initiate military action against ISIS. Those bombing and military training efforts are a long way from sending combat troops, much less a large number of combat troops to the region. Nonetheless, two leading scholars of the Vietnam War asked, 'Will Syria Be Obama's Vietnam?', as early as October 2014. This may seem alarmist,

${ }^{45}$ State Department Draft Dissent Memo on Syria, "New York Times," (17 June 2016) available at www.nytimes.com/interactive/2016/06/17/world/middleeast/document-state-dept-syria. html (accessed on 21 August 2016); David E. Sanger, Kerry Meets with State Department Dissenters Urging Action on Syria, "New York Times," (21 June 2016) available at www.nytimes. com/2016/06/22/us/politics/syria-kerry-diplomats-dissent.html (accessed on 21 August 2016).

${ }^{46}$ J. F. Jeffrey, How to Defeat ISIS: The Case for U.S. Ground Forces, "Foreign Affairs" (4 June 2016) available at www.foreignaffairs.com/articles/syria/2016-01-04/how-defeat-isis (accessed on 26 August 2016). 
but 'War has a forward motion of its own. Most of [President Lyndon] Johnson's major steps in the escalation in Vietnam were in response to unforeseen obstacles, setbacks, and shortcomings. There's no reason the same dynamic couldn't repeat itself in 2014' or later. ${ }^{47}$

There is already evidence of mission creep as the American military role in both Iraq and Syria has expended. To cite one example from Iraq, Obama argued at the time of the first anti-Islamic State air strikes there that the U.S. would not become the 'Iraqi air force,' but that is effectively what has happened. ${ }^{48}$ More relevant for this study is that the same general point can be made about growing U.S. involvement in Syria. The first bombing raids there were conducted on September 15, 2014 and continue. Congress passed an appropriations resolution in September of that year that authorized the Department of Defense to establish a program to train, equip, and sustain appropriately vetted members of the Syrian opposition, i.e., a new program in addition to the existing CIA program. By October 2015, the U.S. was dropping ammunition directly into Syria. While U.S. forces were training and advising opposition forces outside the country, they were not authorized to undertake direct action in Syria, itself, until November 2015, when it was announced that Special Forces units in Iraq could also operate in Syria. Fifty commandos arrived in Syria, itself, in December 2015. Their mission was to embed themselves with Syrian opposition groups to gather intelligence, order air strikes, and plan logistics. ${ }^{49}$

Even with these actions, the U.S. has taken only a few steps on the slippery slope to sending large numbers of combat troops. Still, one can imagine situations when it might. Suppose, for example, that Syrian forces attacked groups backed by the United States? Secretary of Defense Ashton Carter has told the Senate that U.S. has an 'obligation' to defend those groups and that the U.S. military is authorized to do so. ${ }^{50}$ Some are arguing that it should go further. Kori Schake, a fellow at the Hoover Institution, has argued that 'No one... will dare to admit the obvious: we're going to need to put boots on the ground in Iraq and Syria' and that the administration's 'halfhearted commitment of air power...shows few signs of

${ }^{47}$ F. Logevall and Gordon M. Goldstein, Will Syria Be Obama's Vietnam? "New York Times" (7 October 2014) available at www.nytimes.com/2014/10/08/opinion/will-syria-be-obamas-vietnam.html (accessed on 29 August 2014).

${ }^{48}$ Obama quoted in Michael D. Shear and Julie Hirshfeld Davis, While Offering Support, Obama Warns That U.S. Will Not be 'Iraqi Air Force', "New York Times" (8 August 2014) available at www.nytimes.com/2014/08/09/world/middleeast/while-offering-support-obama-warnsthat-us-wont-be-iraqi-air-force.html (accessed on 25 August 2016).

${ }^{49}$ M. Zenko, Your Official Mission Creep Timeline of the U.S. War in Syria, "Foreign Policy" (19 October 2016) available at http://foreignpolicy.com/2015/10/19/official-mission-creep-timeline-us-war-in-syria-obama-administration/ (accessed on August 26, 2016); Paul McLeary, American Commandos Hit the Ground in Syria, "Foreign Policy" (17 December 2015) available at http://foreignpolicy.com/2015/12/17/american-commandos-hit-the-ground-in-syria/ (accessed on 26 August 2016).

${ }^{50}$ Blanchard and Humud, The Islamic State and U.S. Policy, op. cit. 
limiting the Islamic State's gains, not to mention those of the Assad regime.' The actual defeat of the Islamic State will require capturing and occupying its territory. How many Americans? Stephen Biddle and Jacob Shapiro have estimated that doing so will require 'well over' 100,000 Western troops. Because no one in the West contemplates such an effort, 'we're not actually going to solve the problem,' so the best the U.S. can do is to try to contain the Islamic State and not defeat it. ${ }^{51}$

\section{RISKS OF RELYING ON IRREGULAR LOCAL FORCES}

The unwillingness to date to send large numbers of its own combat troops is one reason the U.S. has emphasized working with local allies - the Iraqi military and Syrian rebels. This is an approach Americans should be familiar with and skeptical about. Reviewing the history of American efforts to train foreign fighters, one can conclude that the 'United States has spent untold billions training, equipping, and advising fighters in Iraq, Afghanistan, and Syria, only to see the beneficiaries of their investment run for the hills at the earliest opportunity. ${ }^{52}$ The current American effort supports this conclusion. The Department of Defense program to train and equip up to 5,400 Syrian fighters had become a complete disaster by October 2015. The first US-trained fighters (54 in total) entered Syria in July and were soon attacked by an al Qaeda- affiliated group and almost completely wiped out. A second group entered the country on September 20, 2015 and within two days handed over $25 \%$ of its weaponry to the al-Nusra front, a terrorist group, in order to gain safe passage to northern Syria. As a result of those defeats, the Pentagon admitted in October that only 'four or five' U.S.-trained rebels remained on the battlefield. One month later, the U.S. announced a 'pause' in the training program. It was later replaced by one that relied on support for vetted leaders already fighting in Syria rather than vetting and training new leaders..$^{53}$

${ }^{51}$ K. Schake, The Inherent Fallacy of Believing We Can Beat the Islamic State Without U.S. Ground Troops, "Foreign Policy" (20 April 2016) available at http://foreignpolicy.com/2016/04/20/ the-u-s-cant-beat-the-islamic-state-without-ground-troops-and-no-one-will-admit-it/ (accessed on 28 August 2016); Stephen Biddle and Jacob Shapiro, Here's why we can only contain the Islamic State, not bomb it back to the Stone Age, "Washington Post" (1 December 2015) available at https://www.washingtonpost.com/news/monkey-cage/wp/2015/12/01/heres-why-we-can-onlycontain-the-islamic-state-not-bomb-it-back-to-the-stone-age/ (accessed on 28 August 2015).

${ }^{52}$ R. Brooks, The Hard Lessons of Kunduz and Syria: Why U.S. efforts to train and equip friendly foreign fighters around the world so often fail, "Foreign Policy" (2 October 2015) available at http://foreignpolicy.com/2015/10/02/the-hard-lessons-of-kunduz-and-syria-train-andequip-special-forces/ (accessed on 28 August 2016).

${ }^{53}$ P. McLeary, The Pentagon Just Spent \$41 Million to Train 'Four or Five'Syrian Fighters, "Foreign Policy" (16 September 2015) available at http://foreignpolicy.com/2015/09/16/pentagonjust-spent-41-million-to-train-four-or-five-syrian-fighters/ (accessed on 28 August 2015); Zenko, Your Official Mission Creep Timeline of the U.S. War in Syria, op. cit. 
Yet there is reason to doubt that the new program will have any more success than the previous effort. For one thing, it has proven difficult to recruit 'moderate' fighters. The war has been going on for more than four years with much brutality on all sides, so the 'concept of nice rebels made little sense in a brutal, multipolar civil war involving intermixed populations.' Thus, of the 4,000 applicants for the first group of trainees, only 400 were accepted.$^{54}$ Still, the U.S. cannot be certain that those who are accepted into the program will fight as the U.S. hopes, because their interests and American interests might not coincide: 'People fight and die for what they care about. When fighting for U.S. interests is convenient or lucrative - and not too dangerous - they'll fight for what we care about, too,' but 'when push comes to shove, there's no particular reason for an Iraqi [or Syrian] Sunni to keep fighting the Islamic State when cutting a deal offers a greater likelihood of his family's long-term survival.... ${ }^{55}$

\section{WEAPONS GOING TO THE WRONG HANDS}

Any effort to provide arms to foreign forces runs the risk of 'blowback,' i.e., the danger that those weapons may later be used against you. A recent study gives evidence of the scope of the problem. Researchers examining Pentagon contracts between 2001-2015 found that it sent 1.45 million weapons to Afghan and Iraqi forces, but has records for only approximately 700,000 of those. Not only can all weapons not be accounted for, but the 'recipients were often manifestly corrupt and sometimes had close ties to the same militias and insurgents who were trying to drive out the United States and make sure its entire nation-building project did not stand. ${ }^{56}$ In contemporary Iraq and Syria, an October 2014 report, based on post-battle findings in Kurdish regions, found that $28 \%$ of the cartridges used by IS had been manufactured in Russia or the Soviet Union and another $20 \%$ had been manufactured in the U.S. This suggests that the group is capturing, stealing, or buying American arms from Iraqi forces. The seizure of Mosul in June 2014 netted the Islamic State lots of American-made weaponry: more than 2,000 armored vehicles, forty tanks, and 74,000 rifles with a total value of more than $\$ 600$

${ }^{54}$ Lynch, The New Arab Civil Wars, op. cit., pp. 200-201; Islamic State conflict: US begins training Syrian rebels, "BBC News" (7 May 2015) available at www.bbc.com/news/world-us-canada-32617329 (accessed on 29 August 2016).

${ }_{55}^{5}$ Brooks, The Hard Lessons of Kunduz and Syria, op. cit.; see also Biddle and Shapiro, Here's why we can only contain the Islamic State, not bomb it back to the Stone Age, op. cit.

${ }^{56}$ C.J. Chivers, How Many Guns did the U.S. Lose Track of in Iraq and Afghanistan? Hundreds of Thousands, "New York Times" (24 August 2016) available at www.nytimes.com/2016/08/23/ magazine/how-many-guns-did-the-us-lose-track-of-in-iraq-and-afghanistan-hundreds-of-thousands.html?emc=eta1 (accessed on 29 August 2016). 
million. Now, the U.S. is sending more arms to the country. ${ }^{57}$ While the U.S. has provided far less military aid to the Syrian opposition, the dangers of blowback are present. Two June 2016 news reports are illustrative. Following defeat of an attack by U.S.-sponsored rebels in late June, ISIS released a video showing that it had captured machine guns, ammunition, and a pick-up truck configured to carry a heavy machine gun. There were also reports that millions of dollars of arms sent to Jordan and intended for Syrian rebels had been stolen by Jordanian intelligence officials and sold on the black market. While it is doubtful that all of those arms went to ISIS, it is naïve to think that none did..$^{58}$

U.S. law requires that the recipients of American arms allow the Defense Department to monitor their use, but this is a difficult challenge. Joseph Christoff, who directed the General Accounting Office's efforts to monitor Iraqi compliance before 2011, has stated that 'We faced an enormous [monitoring] challenge when we, in effect, owned Iraq and had many bases where we could do this type of training,' so 'I don't know how we're going to do it securely in this new program. ${ }^{59}$

While the blowback phenomenon typically refers to later use of weapons you provided against you, the Syrian conflict has illustrated another possibility: weapons you provided to two different groups being used against each other. A March 2016 report described clashes between the Pentagon-supported Syrian Democratic Forces, $80 \%$ of whom are Kurdish, and the CIA-backed Knights of Righteous in the area between Aleppo and the Turkish border. The clashes had been going on for at least two months, because the two groups had been brought into closer proximity by Syrian government and Russian air attacks. There was renewed fighting between the groups in August. ${ }^{60}$

${ }^{77}$ E. Pianin, U.S. Shoots Itself in the Foot by Accidently Arming ISIS, "Fiscal Times" (4 June 2015) available at www.thefiscaltimes.com/2015/06/04/Fog-War-US-Has-Armed-ISIS (accessed on August 26, 2016); Leah Schulz, U.S. Factsheet Details New Spike in U.S. Military Aid to Iraq, "Security Assistance Monitor" (14 September 2015) available at http://securityassistance. org/blog/us-factsheet-details-new-spike-us-military-aid-iraq (accessed on 26 August 2015); Julia Harte and R. Jeffrey Smith, Wear Does the Islamic State Get Its Weapons? "Foreign Policy" (6 October 2014), available at http://foreignpolicy.com/2014/10/06/where-does-the-islamic-stateget-its-weapons/ (accessed on 28 August 2016).

${ }^{58}$ H. Johnson, P. McLeary, The Islamic State Just Got Their Hands on More US Weapons, "Foreign Policy" (29 June 2016) available at http://foreignpolicy.com/2016/06/29/the-islamicstate-just-got-their-hands-on-more-u-s-weapons-syria-rebels/ (accessed on 26 August 2016); Mark Mazzetti and Ali Younes, C.I.A. Arms for Syrian Rebels Supplied Black Market Officials Say, "New York Times" (26 June 2016) available at www.nytimes.com/2016/06/27/world/middleeast/cia-arms-for-syrian-rebels-supplied-black-market-officials-say.html?_r=0 (accessed on 26 August 2016).

${ }^{59}$ Christoff quoted in Harte and Smith, Wear Does the Islamic State Get Its Weapons? op. cit.

${ }^{60}$ Nabih Bulos, W.J. Hennigan and Brian Bennett, In Syria, militias armed by the Pentagon fight those armed by the CIA, "Los Angeles Times (27 March 2016) available at www.latimes.com/world/middleeast/la-fg-cia-pentagon-isis-20160327-story.html (accessed on 28 August 2016); Anne Barnard, In Syria, Rebels Threaten Kurdish-Controlled Territory as U.S. Allies Clash, "New York Times" (298August 2016) available at http://www.nytimes.com/2016/08/29/world/ 


\section{CONCLUSIONS}

This study has outlined the contentious debates about the use of military power in the Obama administration. In those debates, the President consistently opposed the use of American power in the period before the summer of 2014 and then, after agreeing to use force against the Islamic State, opposed more energetic military efforts. In both periods, his position was contrary to that of many of his senior advisers. $\mathrm{He}$ also seemed disengaged from these debates. As described in one journalistic account, 'Mr. Obama rarely voiced strong opinions during senior staff meetings. But current and former officials said his body language was telling: he often appeared impatient or disengaged while listening to the debate, sometimes scrolling through messages on his BlackBerry or slouching and chewing gum. ${ }^{\text {'61 }}$

What explains Obama's hesitance? His objections to particular military actions were identified above. More generally, he opposes what he has referred to as the 'Washington playbook,' that 'prescribes responses to different events, and these responses tend to be militarized responses. Where America is directly threatened, the playbook works. But the playbook can also be a trap that can lead to bad choices.' Later in the same interview, he argued that 'What I think is not smart is that every time there is a problem, we send in our military to impose order. We just can't do that.' ${ }^{62}$ The results of American interventions in Iraq, which Obama opposed, and Libya, which he supported, seem to support this conclusion and justify his initial failure to intervene in Syria. As Philip Gordon, a former senior Obama adviser on the Middle East, once noted: 'In Iraq, the U.S. intervened and occupied, and the result was a costly disaster. In Libya, the U.S. intervened and did not occupy, and the result was a costly disaster. In Syria, the U.S. neither intervened nor occupied, and the result is a costly disaster. ${ }^{63}$

Yet Obama did authorize military force against the Islamic State. This led one observer to lament that 'If even Obama could not enduringly reduce America's military presence in the Middle East, could anyone?' ${ }^{64}$ Perhaps the emergence of some of the adverse consequences Obama had predicted the use of American military power and the likely long-term disaster resulting from the effort against the Islamic State will serve to dissuade future Presidents from military action in the Middle East.

middleeast/syrian-rebels-isis-kurds-turkey.html?emc $=$ eta1\&_r=0 (accessed on 29 August 2016); Anne Barnard, In Syria, Rebels Threaten Kurdish-Controlled Territory as U.S. Allies Clash, "New York Times" (28 August 2016) available at www.nytimes.com/2016/08/29/world/middleeast/syrian-rebels-isis-kurds-turkey.html (accessed on 16 September 2016).

${ }^{61}$ Mazzetti, Worth, and Gordon, Obama's Uncertain Path Amid Syrian Bloodshed, op. cit.

${ }^{62}$ Obama quoted in Goldberg, 'The Obama Doctrine, 'op. cit.

${ }^{63}$ P. Gordon, The Middle East is Falling Apart: America isn't to blame. There is no easy fix., "Politico Magazine" (4 June 2015) available at www.politico.com/magazine/story/2015/06/america-not-to-blame-for-middle-east-falling-apart-118611_Page3.html\#.V9kFOK1nFPY (accessed on 14 September 2016).

${ }^{64}$ Lynch, The New Arab Wars, op. cit., p. xiv. 